\title{
Promoting Social and Emotional Development Is an Essential Part of Students' Education
}

\author{
Joseph A. Durlak ${ }^{a}$ Roger P. Weissberg ${ }^{b}$ \\ a Loyola University Chicago and ${ }^{\mathrm{b} C o l l a b o r a t i v e ~ f o r ~ A c a d e m i c, ~ S o c i a l ~ a n d ~ E m o t i o n a l ~}$ \\ Learning, University of Illinois at Chicago, Chicago, III., USA
}

The disappointing educational outcomes achieved in many of our nation's schools have been the focus of much attention, but usually from a negative perspective. That is, some point the finger at students who do not seem motivated and do not put in enough effort, others blame teachers for not getting the most out of their students, and others criticize parents for their lack of involvement and support. Sometimes, school leaders decry ever-changing state and federal policies and standards that impede any consistency or innovation in pedagogical curricula. Still others point to taxpayers' frequent failure to back proposals for adequate and equitable school funding. Yet, the focus on problems and who's to blame for them has failed to solve the current predicament that too many students either do not graduate, or finish school unprepared for becoming successful adult citizens. Here we describe findings from a large-scale research review that concludes that promoting students' social and emotional development can have broad implications for student learning, achievement and behavior [Durlak, Weissberg, Dymnicki, Taylor, \& Schellinger, 2011].

We examined the outcomes that were obtained by 213 controlled published and unpublished outcome studies that involved over 270,000 students. Each study evaluated a social and emotional learning (SEL) program and compared the outcomes to students participating in these programs to those in control groups. SEL is defined as the process of acquiring the skills to recognize and manage emotions, set and achieve positive goals, appreciate the perspectives of others, establish and maintain positive relationships, make responsible decisions, and handle interpersonal situations effectively. The interventions we evaluated were universal in scope in that they were offered to all students in participating classes or schools rather than to any select groups. Our review sought to determine which outcomes could be achieved via SEL programs, how much change students displayed as a result of their participation, and which operational program features were associated with better results.

\begin{tabular}{ll}
\hline KARGER & ( ) 2011 S. Karger AG, Basel \\
Fax +41 61 306 12 34 & 0018-716X/11/0541-0001\$38.00/0 \\
$\begin{array}{l}\text { E-Mail karger@karger.ch } \\
\text { www.karger.com }\end{array}$ & $\begin{array}{l}\text { Accessible online at: } \\
\text { www.karger.com/hde }\end{array}$
\end{tabular}

Joseph Durlak

Psychology Department, Loyola University Chicago 1032 W. Sheridan Road

Chicago, IL 60660 (USA)

Tel. +1 505466 1488, E-Mail jdurlak@luc.edu 
Our findings indicated that school-based SEL programs produce multiple positive outcomes and that SEL programs are one of the best strategies for fostering students' development in multiple areas. For example, SEL programs led to significant improvement in students' social and emotional skills, their attitudes about themselves and their school, and their social and classroom behavior. SEL programs were also associated with significant reductions in students' conduct problems such as classroom misbehavior and aggression, and their emotional distress reflected in symptoms of anxiety, depression or stress. Most important, participation in SEL programs was also associated with gains in achievement test scores and school grades that corresponded to an 11th-percentile point gain in academic achievement. These latter results indicate that SEL programs do not come at the expense of performance in core academic skills, but can enhance academic achievement. Moreover, the positive findings were present for students in elementary, middle and high school, in schools located in urban, rural and suburban areas and in schools serving ethnically and culturally diverse student bodies. Finally, across the different outcomes we examined, the amount of change demonstrated by SEL participants was either equal to, or better than those achieved by other universal school-based interventions that have been carefully evaluated.

There were 3 other major findings. First, SEL programs were successfully conducted by existing school staff. Second, school staff that followed 4 evidence-based practices in terms of developing new skills had students who showed more improvements than the students in schools where staff did not use all 4 practices. These practices included offering a sequential and integrated skills curriculum or program, using active forms of learning to promote skills, focusing sufficient attention on skill development, and establishing explicit learning goals. Third, implementation quality matters; positive findings were more likely when programs were well conducted and according to plan.

These results and other research studies [Durlak, Weissberg, \& Pachan, 2010; Greenberg, Weissberg, O’Brien, Zins, Fredericks, Resnik, \& Elias., 2003; Zins, Weissberg, Wang, \& Walberg, 2004] have important implications for education policy and practice. They indicate that well-designed, well-implemented, teacher-taught SEL programs can achieve multiple benefits that include significant improvement in students' social-emotional development, behavior and academic performance, and that SEL programs are among the most successful of all school-based universal interventions. Furthermore, SEL programs can be effectively integrated into routine educational practice and can be successfully applied in many of our nation's schools.

Readers may wonder what to make of our findings given the attention recently given to the Institute of Education Sciences (IES) study of character education programs that reported these interventions failed to improve students' social and emotional development, behavior or academic achievement [Social and Character Development Research Consortium, 2010]. Our review and the IES study had very different purposes. The IES study only evaluated 7 character education programs, and its methods of analysis have been the subject of controversy. Our review examined the collective impact of over 200 outcome studies, most of which had already undergone scientific peer review. However, both our review and the IES study underscore the importance of high-quality program implementation. In several instances, programs in the IES study were not implemented very well. For example, more than half of one set of analyses indicated that intervention teachers failed to use prescribed 
program materials or instructional methods in their classrooms significantly more than teachers in the control group, suggesting intervention students were not receiving critical aspects of the proposed program. Therefore, it is essential that schools receive sufficient technical assistance when implementing new programs. It is also important to identify which specific SEL programs have been evaluated carefully and have achieved positive effects on different outcomes in order to guide educators in the choice of an intervention that suits each school's needs. This is the focus of a soon-to-be completed Collaborative for Academic, Social and Emotional Learning report that will be released in the coming months (see casel.org).

Effective SEL programming by school personnel must be supported by coordinated federal, state and local educational policies, leadership, and professional development to foster the best outcomes. It is critical to support inclusion of evidencebased SEL programming in federal legislation such as HR 4223 (Academic, Social and Emotional Learning Act of 2009) and the reauthorization of the Elementary and Secondary Education Act. A recent report by the Substance Abuse and Mental Health Services Administration to Congress stated that Illinois has taken the lead on this front by introducing SEL standards as part of their student learning standards. Other states, such as New York, are following this direction. Combining sound educational policy and support to school personnel who deliver evidence-based SEL programming is an important strategy to maximize the social, emotional and academic growth of all children and youths.

In sum, while numerous changes are necessary to improve educational and life outcomes for all children, SEL programs can provide students with important tools to improve both school and life success. SEL programs are not a panacea, but now there is a strong evidence base that suggests they can be part of the solution for enhancing students' social, personal and academic development. Actually, this statement should not be a surprise given both behavioral and neuroscience research showing the deep interrelatedness of various aspects of human development. Promoting positive development in one domain can lead to concomitant positive changes in other areas. Fostering young people's personal and social development should be a fundamental focus of our educational institutions.

\section{References}

Durlak, J.A., Weissberg, R.P., Dymnicki, A.B., Taylor, R.D., \& Schellinger, K.B. (2011). The impact of enhancing students' social and emotional learning: A meta-analysis of school-based universal interventions. Child Development, 82, 474-501.

Durlak, J.A., Weissberg, R.P., \& Pachan, M. (2010). A meta-analysis of after-school programs that seek to promote personal and social skills in children and adolescents. American Journal of Community Psychology, 45, 294-309.

Greenberg, M.T., Weissberg, R.P., O’Brien, M.U., Zins, J.E., Fredericks, L., Resnik, H., \& Elias, M.J. (2003). Enhancing school-based prevention and youth development through coordinated social, emotional, and academic learning. American Psychologist, 58, 466-474.

Social and Character Development Research Consortium (2010). Efficacy of schoolwide programs to promote social and character development and reduce problem behavior in elementary school children (NCER 2011-2001). Washington: National Center for Education Research, Institute of Education Sciences, US Department of Education.

Zins, J.E., Weissberg, R.P., Wang, M.C., \& Walberg, H.J. (Eds.) (2004). Building academic success on social and emotional learning: What does the research say? New York: Teachers College Press.

Promoting Social and Emotional Development

Human Development 